\title{
ANNUAL LIST OF PUBLISHED PAPERS
}

READ BEFORE THE AMERICAN MATHEMATICAL SOCIETY, TOGETHER WITH THE PLACES OF THEIR PUBLICATION.

Haskela, M. W. On the Introduction of the Notion of Hyperbolic Functions. Read Dec. 28, 1894. Bulletin of the American Mathematical Society, 2d series, vol. 1, No. 6, pp. 155-159, March, 1895.

HILI, G. W. Literal Expression for the Motion of the Moon's Perigee. Read Oct. 2\%, 1894. Annals of Mathematics, vol. 9, No. 2, pp. 3141, Jan., 1895.

Johnson, W. Woouser. Kinetic Stability of Central Orbits. Read April 2\%, 1895. Bulletin of the American Mathematical Society, 2d series, vol. 1, No. 8, pp. 193-196, May, 1895.

McClintock, Emory. A Method for Calculating Simultaneously All the Roots of an Equation. Read Aug. 14 and Oct. 2\%, 1894. American Journal of Mathematics, vol. 17, No. 2, pp. 89-110, April, 1895.

- Theorems in the Calculus of Enlargement. Read Aug. 14, 1894. American Journal of Mathematics, vol. 17, No. 1, pp. 69-80, Jan., 1895.

- The Past and Future of the Society. [Presidential Address.] Read Dec. 28, 1894. Bulletin of the American Mathematical Society, 2d series, vol. 1, No. 4, pp. 85-94, Jan., 1895.

Martin, Artemas. About Cube Numbers whose Sum is a Cube Number. Read Aug. 15, 1894. Mathematical Magazine, vol. 2, No. 9, pp. 153-160, Jan., 1895.

Moore, E. Hastings. Concerning the Definition by a System of Functional Properties of the Function $f(z)=\sin \pi z / \pi$. Read Aug. 15, 1894. Annals of Mathematics, vol. 9, No. 2, pp. 43-49, Jan., 1895.

- The Group of Holoedric Transformation into Itself of a Given Group. Read Nov. 24, 1894. Bulletin of the American Mathematical Society, 2d series, vol. 1, No. 3, pp. 61-66, Dec., 1894.

Morley, F. Apolar Triangles on a Conic. Read Jan. 26, 1895. Bulletin of the American Mathematical Society, $2 \mathrm{~d}$ series, vol. 1, No. 5, pp. 116-124, Feb., 1895.

Roberts, Ralph A. On a Certain Class of Canonical Forms. Read Dec. 28, 1894. Bulletin of the American Mathematical Society, 2d series, vol. 1, No. 5, pp. 105-111, Feb., 1895.

Schleger, V. Upon the Problem of the Minimum Sum of the Distances of a Point from Given Points. Read Aug. 15, 1894. Bulletin of the American Mathematical Society, 2d series, vol. 1, No. 2, pp. 33-52, Nov., 1894.

White, Henry S. Reduction of the Resultant of a Binary Quadric and $n$-ic by Virtue of its Semi-Combinant Property. Read Aug. 15, 1894. Bulletin of the American Mathematical Society, 2d series, vol. 1, No. 1, pp. 11-15, Oct., 1894.

Woodwand, R. S. On the Derivation of the Equations of Rotation of Bodies of Variable Form. Read April 27, 1895. Included in article: Mechanical Interpretation of the Variations of Latitudes, Astronomical Journal, No. 345, vol. 15, pp. 65-72, May 21, 1895. 